\title{
Protein-energy supplementation frequency on ruminal variables, intake and digestibility in steers receiving low quality hay
}

\section{Frequência de suplementação proteico-energética sobre as variáveis ruminais, ingestão e digestibilidade em novilhos recebendo feno de baixa qualidade}

Marcella Cândia D’Oliveira' (D), Fábio Arguelo Biberg¹ (D), Gabriela Facholi Bomfim¹ (D), Maria da Graça Morais ${ }^{1}$ (D) , José Mauro Diogo ${ }^{1}$ (D) , Gumercindo Loriano Franco ${ }^{*}$

1Universidade Federal do Mato Grosso do Sul, Campo Grande, MS, Brazil.

*Correspondent - gumercindo.franco@ufms.br

\begin{abstract}
The aim was evaluated the effect of reduce in proteinenergy supplementation frequency on nutrients intake, forage digestibility and degradability, as well as, ruminal $\mathrm{pH}$ and ammonia nitrogen $\left(\mathrm{N}-\mathrm{NH}_{3}\right)$ concentration in beef cattle receiving low-quality hay. A $4 \times 4$ Latin square design were used. Four steers were fed with low-quality hay and subjected to four treatments: no supplementation (control); protein-

energy supplementation with $0.82 \%$ of body weight (BW) offered three times per week (3WK); $0.49 \%$ of BW offered five times a week ( 5 WK), and $0.35 \%$ of BW offered seven times per week (7 WK). The use of protein-energy supplementation increased intake of dry matter (DM), crude protein (CP), neutral detergent fiber (NDF), ether extract (EE), non-fibrous carbohydrates (NFC) and the digestibility coefficients of CP, EE, and NFC. However, no differences in DM and NDF degradation were observed between treatments in the evaluated hay. Supplementation did not alter ruminal $\mathrm{pH}$, but the $\mathrm{N}-\mathrm{NH}_{3}$ concentration was highest in treatment 7WK. Reduction in protein-energy supplementation frequency of daily to $3 \mathrm{WK}$ or 5WK does not negatively affect intake, digestibility and degradability of nutrients in beef cattle receiving low quality hay.
\end{abstract}

Section: Zootecnia

Received

October 10, 2018

Accepted

October, 16, 2019

Published

March 13, 2020

www.revistas.ufg.br/vet

visit the website to get the how to cite in the article page.
Keywords: beef production, nutrients degradability, ruminal $\mathrm{pH}$, ruminal ammonia nitrogen

\footnotetext{
Resumo

Objetivou-se avaliar o efeito da redução na frequência de suplementação proteico-energética sobre o consumo de nutrientes, degradabilidade e digestibilidade da forragem, assim como o pH e concentração de nitrogênio amoniacal (N$\mathrm{NH}_{3}$ ) ruminal em bovinos de corte recebendo feno de baixa qualidade. Foi utilizado o delineamento quadrado latino de 4 x 4. Quatro bovinos foram alimentados com feno de baixa qualidade e submetidos aos seguintes tratamentos: sem suplementação (controle); suplementação com 0,82\% do peso corporal (PC), três vezes por semana (3x); 0,49\% do PC, cinco vezes por semana (5x); e 0,35\% do PC sete vezes por semana (7x). O uso do suplemento proteico-energético aumentou a ingestão de matéria seca (MS), PB (proteína bruta), FDN (Fibra em detergente neutro), EE (extrato etéreo), CNF (carboidratos
} 
não fibrosos) e os coeficientes de digestibilidade da PB, EE e CNF. Entretanto, não foram observadas diferenças na degradação da MS e FDN do feno entre os tratamentos. A suplementação não alterou o $\mathrm{pH}$ ruminal, mas a concentração de nitrogênio amoniacal $\left(\mathrm{N}-\mathrm{NH}_{3}\right)$ foi maior no tratamento $7 x$. A redução na frequência de suplementação proteico-energética diária para $3 x$ ou $5 x$ não afetou negativamente o consumo, digestibilidade e degradabilidade dos nutrientes em bovinos de corte recebendo feno de baixa qualidade.

Palavras chave: produção de bovinos, degradabilidade dos nutrientes, pH ruminal, amônia ruminal, nitrogênio.

\section{Introduction}

In ruminants, the grazing system with the use of low nutritional quality forage combined with the seasonality of forage production could result in loss of weight. In order to sustain cattle, the feed derived from pasture must often be supplemented. This supplementation can be expensive including the purchase, transportation, and distribution of feed supplements and the labor involved in these tasks. Therefore, the determination of types of supplementation and the frequency to be used is important to sustain cattle in cost efficient systems. Several studies have demonstrated the feasibility of minimizing costs of distribution of supplements for beef cattle without affecting the productive performance of animals through less frequent supplementation during the rainy season ${ }^{(1,2,3)}$. Decreased frequency of supplementation also results in reduced labor and equipment costs associated with supplementation.

The lowest frequency of protein-energy supplementation to ruminants consuming low quality forage has been shown to maintain efficient levels of ruminal nitrogen (N), both in sheep ${ }^{(4)}$ and cattle ${ }^{(5)}$, when compared with daily supplementation. This probably results from the ability of ruminants to recycle nitrogen.

Few studies have investigated a reduction in the frequency of supplementation when the animals are fed with low quality hay. The hypothesis investigated here is that reducing the frequency of protein-energy supplementation to three times per week should not modify the feed digestion by the cattle. So, this study evaluated the effect of protein-energy supplementation frequencies on ruminal variables $\left(\mathrm{pH}\right.$ and $\left.\mathrm{N}-\mathrm{NH}_{3}\right)$, voluntary DMI, DM degradability, forage neutral detergent fiber(NDF), and total apparent digestibility in crossbred cattle receiving low-quality hay.

\section{Materials and methods}

All animal procedures were approved by the Animal Care and Use Committee of Universidade Federal de Mato Grosso do Sul (UFMS), Brazil.

Four steers rumen-cannulated crossbred ( $1 / 2$ Aberdeen Angus $1 / 2$ Nellore) with average initial body weight of $515 \pm 30 \mathrm{~kg}$ were used. The animals were housed in individual pens with water pans and feeders in a completely covered shed with concrete floor and 
water was provided ad libitum.

The animals were fed with Aruana-grass hay [Megathyrsus maximus (Jacq.) B.K. Simon \& S.W.L. Jacobs] and subjected to four treatments with the following protein-energy supplementation frequencies: control treatment (without supplementation - receiving only $80 \mathrm{~g}$ of mineral mixture/day), 3WK (supplementation received three times a week Monday, Wednesday, and Friday), 5WK (supplementation received five times per week - Monday to Friday), and 7WK (supplementation received daily).

The supplement was formulated according to $N R C^{(6)}$ recommendations by combining ground corn $(557.3 \mathrm{~g} / \mathrm{kg})$, soybean meal $(409.8 \mathrm{~g} / \mathrm{kg})$, urea $(5.5 \mathrm{~g} / \mathrm{kg})$, and mineral mixture $(27.4 \mathrm{~g} / \mathrm{kg})$ on a dry basis and meeting the requirements of rumen microorganisms and metabolizing protein for a gain of approximately $0.280 \mathrm{~kg} /$ animal/day (Table 1).

Table 1. Chemical composition of Aruana-grass hay and protein-energy supplement

\begin{tabular}{lcccccccc}
\hline & \multirow{2}{*}{ Item } & \multicolumn{7}{c}{ Chemical composition (g/kg DM) } \\
\cline { 3 - 9 } & $(\mathbf{g} / \mathbf{k g})$ & CP & Ash & OM & $\begin{array}{c}\text { NDFrom } \\
\text { cp }\end{array}$ & EE & NFC & TDN \\
\hline Aruana hay & 888.3 & 36.0 & 75.2 & 924.8 & 781.0 & 16.5 & 91.3 & $409.18^{2}$ \\
Supplement $^{1}$ & 909.9 & 236.6 & 65.0 & 935.0 & 86.2 & 27.4 & 544.7 & $820.33^{3}$ \\
\hline
\end{tabular}

${ }^{1}$ Mineral mixture $(2.74 \mathrm{~kg} / 100 \mathrm{~kg}):(145.4 \mathrm{~g} / \mathrm{kg} \mathrm{Ca}, 40 \mathrm{~g} / \mathrm{kg} \mathrm{P}, 175.8 \mathrm{~g} / \mathrm{kg} \mathrm{Na}, 8.1 \mathrm{~g} / \mathrm{kg} \mathrm{S}, 2800$ $\mathrm{mg} / \mathrm{kg} \mathrm{Zn,} 520 \mathrm{mg} / \mathrm{kg} \mathrm{Mn}, 50 \mathrm{mg} / \mathrm{kg} \mathrm{Co}, 980 \mathrm{mg} / \mathrm{kg} \mathrm{Fe}, 5.9 \mathrm{mg} / \mathrm{kg} \mathrm{Se}, 64.9 \mathrm{mg} / \mathrm{kg} \mathrm{I}, 400$ $\mathrm{mg} / \mathrm{kg} \mathrm{F}, 1100 \mathrm{mg} / \mathrm{kg} \mathrm{Cu}$ and $5.0 \mathrm{mg} / \mathrm{kg} \mathrm{Mg})$.

${ }^{2} \mathrm{TDN}(\%)=91,6086-0,6692(\mathrm{FDN})+0,4379(\mathrm{~PB})^{(7)}$

${ }^{3}$ Tabelas brasileiras de composição de alimentos para bovinos ${ }^{(8)}$.

DM: dry matter, CP: crude protein, OM: organic matter, NDFrom cp (ash-free NDF corrected for crude protein): (NDF-Ash+CP from NDF; $\left.{ }^{(9)}\right)$, EE: ether extract, NFC (non-fibrous carbohydrate): (100-CP+Ash+NDFcp+EE; $\left.{ }^{(9)}\right)$, TDN - Total digestible nutrients.

The animals were fed twice daily, at 8 am and 4 pm. However, the concentrated supplement was always provided at noon in the amount of $0.82 \mathrm{~g} / \mathrm{kg} ; 0.49 \mathrm{~g} / \mathrm{kg}$, and $0.35 \mathrm{~g} / \mathrm{kg}$ of BW per animal/day in the $3 \mathrm{WK}, 5 \mathrm{WK}$, and $7 \mathrm{WK}$ treatments, respectively.

The animals were randomly distributed into a $4 \times 4$ Latin square design over four experimental periods of 21 days each, with 14 days for adaptation to the supplement and 7 days for sample collection

From the 15th to the 21th day of each experimental period feed, feed leftovers, and fecal were monitored and sampled. The voluntary DMI and nutrient intake (NI) of the diets were obtained by the difference between the offered and leftover.

The total amount of feces was collected. After each individual collection, feces were weighed, homogenized, and only $100 \mathrm{~g} / \mathrm{kg}$ of feces of each treatment was kept frozen. At the end of the experiment, these samples were dried, weighed, homogenized, and finely milled for later laboratorial analyses. The apparent digestibility's (AD) dry matter and nutrients were calculated as follows: $A D=$ [(ingested nutrient - nutrient found in 
feces)/ingested nutrient].

Degradability of DM and NDF was determined using the nylon bag technique as described by Ribeiro et al. ${ }^{(10)}$.

The soluble fraction was prepared by placing $5 \mathrm{~g}$ of forage in nylon bags that were sealed and soaked in a water bath for one hour at $38{ }^{\circ} \mathrm{C}$; soluble fraction bags were cleaned and dried using the same procedure for incubated bags. The weight loss was considered as soluble fraction "a", which corresponds to the value at 'time zero' in the DM degradation curve. The soluble fraction "a", insoluble fraction "b", degradation rate " $C$ ", and effective degradability (ED) of DM and NDF were calculated as described by Huntington and Givens ${ }^{(11)}$ as $(E D)=a+(b \times c) /(c+k)$, where $k$ is the passing rate in the rumen (assuming that $\mathrm{k}=0.05 / \mathrm{h}$ ).

Ruminal liquid samples from all animals were collected manually at the start of each collection period (2nd day-Sunday). This time point represents the longest time period between supplementations in the $3 \mathrm{WK}$ and $5 \mathrm{WK}$ treatments. The collections were at $8 \mathrm{am}$ (before feeding), $10 \mathrm{am}, 12 \mathrm{pm}$ (before supplementation), $2 \mathrm{pm}, 4 \mathrm{pm}$ (before feeding), and 8 pm, times equivalent to $44,46,48,50,52$, and 56 hours after the last supplementation in the $3 \mathrm{WK}$ and $5 \mathrm{WK}$ treatments.

Diets, leftovers, and feces were analyzed according to $A O A C^{(12)}$ as follows: method 930.15 was used to determine dry matter (DM); method 942.05 to determine organic matter (OM); method 976.05 to determine crude protein level in total nitrogen (CP); and method 920.39 to determine ether extract (EE).

The filter bag technique using one Tecnal unit (TE-149; Tecnal, Piracicaba, SP, Brazil) was employed for the NDF analyses. A hay sample $(0.5 \mathrm{~g})$ or materials from the in situ ruminal degradation was placed in filter bags (nonwoven fabric, $5 \times 5 \mathrm{~cm}, 100 \mu \mathrm{m}$ porosity). Bags were subsequently submerged in neutral detergent ( $\left.\mathrm{ND}^{(13)}\right)$ inside the Tecnal equipment. Heat-stable alpha-amylase (Thermamil ${ }^{\circledR} 120 \mathrm{l}$ ) was employed in the supplement NDF analyses. Results were not corrected for ash. And NFC was calculated according to $\mathrm{NRC}^{(14)}$.

Because of the presence of urea in the concentrated supplement, the NFC content was calculated as proposed by Hall(15).

Approximately $100 \mathrm{~mL}$ of rumen liquid was obtained manually directly from the fistula. The $\mathrm{pH}$ of freshly prepared ruminal fluid samples was measured in a portable potentiometer (B474; Micronal, São Paulo, SP, Brazil).

A subsequent sample of approximately $50 \mathrm{~mL}$ of ruminal fluid was obtained, acidified with approximately $1 \mathrm{~mL}$ of $\mathrm{H}_{2} \mathrm{SO}_{4}$, and frozen $\left(-15^{\circ} \mathrm{C}\right)$ for further analyses of rumen ammonia content as described by Fenner ${ }^{(16)}$ and adapted by Ribeiro et al. ${ }^{(10)}$.

The data were analyzed in a $4 \times 4$ Latin square design by analysis of variance run in the GLM Procedure (SAS student). When significant F-statistics results were observed $(P<0.05)$, means were separated using a multiple comparison test (Tukey's method) and treatment differences with $P \leq 0.05$ were considered significant. 


\section{Results}

The total DM, OM, total CP, total NDF, and NFC (Table 2) were higher in treatments with supplementation ( $3 \mathrm{WK}, 5 \mathrm{WK}$, and $7 \mathrm{WK}$ ) compared to the control. However, there were no differences among the treatments with supplementation.

Table 2. Intake ( $\mathrm{g} / \mathrm{kg}$ of $\mathrm{BW}$ ) of hay and supplement DM, OM, CP, NDF corrected for CP contamination, EE and NFC in cattle fed at different supplementation frequencies

\begin{tabular}{llllllll}
\hline \multirow{2}{*}{ Intake (g/kg BW) } & \multicolumn{5}{c}{ Treatments $^{\mathbf{a}}$} & & \\
\cline { 2 - 6 } & Control & 3WK & 5WK & 7WK & & PEM \\
\hline Hay DM & $12.41 \mathrm{~b}$ & $14.55 a b$ & $14.91 \mathrm{a}$ & $15.63 \mathrm{a}$ & 0.466 & 0.0129 \\
Total DM & $12.41 \mathrm{~b}$ & $17.51 \mathrm{a}$ & $17.87 \mathrm{a}$ & $18.61 \mathrm{a}$ & 0.452 & 0.0002 \\
OM & $11.50 \mathrm{~b}$ & $16.28 \mathrm{a}$ & $16.59 \mathrm{a}$ & $17.28 \mathrm{a}$ & 0.419 & 0.0002 \\
Hay CP & $0.51 \mathrm{~b}$ & $0.58 \mathrm{ab}$ & $0.59 \mathrm{ab}$ & $0.61 \mathrm{a}$ & 0.017 & 0.0253 \\
Total CP & $0.51 \mathrm{~b}$ & $1.28 \mathrm{a}$ & $1.29 \mathrm{a}$ & $1.32 \mathrm{a}$ & 0.013 & $<0.0001$ \\
Hay NDF & $9.51 \mathrm{~b}$ & $11.25 \mathrm{ab}$ & $11.54 \mathrm{a}$ & $12.05 \mathrm{a}$ & 0.368 & 0.0122 \\
Total NDF & $9.51 \mathrm{~b}$ & $11.50 \mathrm{a}$ & $11.80 \mathrm{a}$ & $12.30 \mathrm{a}$ & 0.367 & 0.0072 \\
EE & $0.22 \mathrm{~b}$ & $0.25 \mathrm{ab}$ & $0.34 \mathrm{ab}$ & $0.35 \mathrm{a}$ & 0.025 & 0.0251 \\
NFC & $1.14 \mathrm{~b}$ & $3.04 \mathrm{a}$ & $3.10 \mathrm{a}$ & $3.17 \mathrm{a}$ & 0.082 & $<0.0001$ \\
\hline
\end{tabular}

Means in the same row with different letters $(a, b)$ are statistically different $(P<0.05)$.

Hay DM: amount of hay DM ingestion, Total DM: Hay DM + supplement DM, Hay CP: amount of hay CP ingestion, Total CP: Hay CP + supplement CP, Hay NDF: amount of hay NDF ingestion, Total NDF: Hay NDF + supplement NDF; SEM: mean standard error.

a Control (without supplementation - receiving only $80 \mathrm{~g}$ of mineral mixture/day), 3WK (supplementation received three times a week - Monday, Wednesday, and Friday), 5WK (supplementation received five times per week - Monday to Friday), and 7WK (supplementation received daily)

The DM apparent digestibility in the 5WK and 7WK treatments (Table 3) was higher than in the control treatment. There was no difference in OM and NDF digestibility among treatments. The CP and NFC digestibility was increased in the supplementation treatments and EE digestibility was higher for 7WK compared to 3WK treatments (Table 3).

No differences in DM and NDF degradation were observed between treatments in the evaluated hay. The potential degradation rate of NDF and DM were achieved after 96 hours of incubation however, without interaction between treatment and incubation time.

No significant differences were observed between the supplementation treatments and control in the DM and NDF fractions " $b$ " and "c"; the same was observed in the 
effective degradation (ED) of these components (Table 4).

Table 3. Apparent digestibility coefficient of DM and contents of digestible $\mathrm{OM}, \mathrm{CP}$, NDF corrected for CP contamination, EE, NFC in diets (hay + supplement) offered to cattle at different frequencies of supplementation

\begin{tabular}{lllllll}
\hline \multirow{2}{*}{ Digestibility } & \multicolumn{2}{l}{ Treatments $^{\mathbf{a}}$} & & & \multirow{2}{*}{ SEM } & \multirow{2}{*}{ P-value } \\
\cline { 2 - 6 } & Control & $\mathbf{3 W K}$ & $\mathbf{5 W K}$ & $\mathbf{7 W K}$ & & \\
\hline DM (fraction 0-1) & $0.519 \mathrm{~b}$ & $0.558 \mathrm{ab}$ & $0.5746 \mathrm{a}$ & $0.583 \mathrm{a}$ & 0.011 & 0.0253 \\
(g/kg DM) & & & & & & \\
OM & 548.5 & 582.0 & 592.3 & 602.4 & 11.35 & 0.0622 \\
$\mathrm{CP}$ & $406.3 \mathrm{~b}$ & $616.1 \mathrm{a}$ & $636.7 \mathrm{a}$ & $635.4 \mathrm{a}$ & 13.60 & $<0.0001$ \\
NDF & 556.2 & 529.2 & 544.3 & 561.8 & 16.17 & 0.5381 \\
EE & $698.3 \mathrm{ab}$ & $638.8 \mathrm{~b}$ & $776.2 \mathrm{ab}$ & $802.1 \mathrm{a}$ & 32.33 & 0.0400 \\
NFC & $474.3 \mathrm{~b}$ & $772.6 \mathrm{a}$ & $751.1 \mathrm{a}$ & $738.0 \mathrm{a}$ & 34.17 & 0.0025 \\
\hline
\end{tabular}

Means in the same row with different letters $(a, b)$ are statistically different $(\mathrm{P}<0.05)$. DM: dry matter, OM: organic matter, CP: crude protein, NDF (neutral detergent fiber) corrected for CP contamination, EE: ether extract, NFC: non-fibrous carbohydrate

a Control (without supplementation - receiving only $80 \mathrm{~g}$ of mineral mixture/day), 3WK (supplementation received three times a week - Monday, Wednesday, and Friday), 5WK (supplementation received five times per week - Monday to Friday), and 7WK (supplementation received daily)

Table 4. Estimation of ruminal parameters and hay DM degradation; values are expressed as a fraction of $0-1$

\begin{tabular}{lllllll}
\hline \multirow{2}{*}{ Parameters $^{\mathbf{a}}$} & \multicolumn{2}{l}{ Treatments $^{\mathbf{a}}$} & & & \multirow{2}{*}{ SEM } & P-value \\
\cline { 2 - 6 } Control & 3WK & 5WK & 7WK & & \\
\hline NDF & & & & & & \\
b & 0.591 & 0.590 & 0.587 & 0.589 & 0.383 & 0.8619 \\
c & 0.037 & 0.042 & 0.038 & 0.044 & 0.129 & 0.0623 \\
ED & 0.252 & 0.270 & 0.255 & 0.275 & 0.759 & 0.2356 \\
DM (a= 0.203) & & & & & & \\
b & 0.420 & 0.432 & 0.418 & 0.412 & 1.208 & 0.8067 \\
C & 0.039 & 0.042 & 0.039 & 0.044 & 0.155 & 0.1529 \\
DE & 0.405 & 0.424 & 0.405 & 0.426 & 1.011 & 0.3469 \\
\hline
\end{tabular}

a: Soluble fraction, b: potentially degradable insoluble fraction, c: degradation rate $(/ \mathrm{h})$, ED: effective degradation (considering a degradation rate of $0.05 / \mathrm{h}$ ).

- Control (without supplementation - receiving only $80 \mathrm{~g}$ of mineral mixture/day), 3WK (supplementation received three times a week - Monday, Wednesday, and Friday), 5WK (supplementation received five times per week - Monday to Friday), and 7WK (supplementation received daily) 
There was no significant interaction between treatments and collection times. Similarly, no significant difference between the mean ruminal $\mathrm{pH}$ observed as $7.09 \pm 0.03 ; 7.16$ \pm 0.03 ; $7.18 \pm 0.03$; and $7.07 \pm 0.03$ for the control, $3 \mathrm{WK}, 5 \mathrm{WK}$, and $7 \mathrm{WK}$ treatments, respectively.

There was no interaction between treatments and the collection times for ruminal $\mathrm{N}-\mathrm{NH}_{3}$. However, there was a significant difference (Table 5) between the 3WK, 5WK, 7WK, and control treatments $(3.77 \pm 0.37 ; 3.87 \pm 0.37 ; 5.61 \pm 0.37$; and $2.24 \pm 0.37$, respectively). Animals in the 7WK treatment showed the highest mean N-NH3 concentration.

Table 5. Mean ruminal $\mathrm{N}-\mathrm{NH}_{3}$ concentration $(\mathrm{mg} / \mathrm{dL})$ in cattle fed at different supplementation frequencies

\begin{tabular}{cccccccc}
\hline \multirow{2}{*}{ Hours } & \multicolumn{2}{l}{ Treatments $^{\mathbf{a}}$} & & & & \multirow{2}{*}{ SEM } & \multirow{2}{*}{ P-value } \\
\cline { 2 - 7 } & Control & 3WK & 5WK & 7WK & Mean & & \\
\hline 8 & 3.07 & 3.64 & 4.83 & 6.02 & 4.39 & & \\
10 & 2.17 & 5.58 & 5.46 & 6.59 & 4.95 & & \\
12 & 2.07 & 4.45 & 2.51 & 4.07 & 3.27 & 0.454 & 0.0612 \\
14 & 2.10 & 3.01 & 2.07 & 6.84 & 3.50 & & \\
16 & 1.51 & 2.57 & 4.35 & 6.99 & 3.85 & & \\
20 & 2.51 & 3.39 & 4.02 & 3.14 & 3.26 & & \\
\hline Mean & $2.67 \mathrm{c}$ & $3.77 \mathrm{~b}$ & $3.87 \mathrm{~b}$ & $5.61 \mathrm{a}$ & & $0.370<0.0001$ \\
\hline
\end{tabular}

Means in the same row with different letters $(a, b, c)$ are statistically different $(P<0.05)$.

a Control (without supplementation - receiving only $80 \mathrm{~g}$ of mineral mixture/day), 3WK (supplementation received three times a week - Monday, Wednesday, and Friday), 5WK (supplementation received five times per week - Monday to Friday), and 7WK (supplementation received daily)

\section{Discussion}

Animals receiving protein-energy supplementation showed higher hay intake and consequently higher nutrient intake than those receiving just mineral mixture in the control treatment (Table 2). McGuire et al.(17) report similar observations in steers receiving protein supplementation daily or on alternating days. However, variability and reduction in DMI results with supplementation are evident in the literature ${ }^{(18)}$. Such variation can be attributed to the quantity and quality of the supplement as well as the feed used. According to Moore et al. ${ }^{(19)}$, the use of supplement increases forage intake when the ratio total digestible nutrients (TDN): $\mathrm{CP}$ is $>7$ indicating that there is a nitrogen deficit in relation to the available energy; reduced forage intake is observed when this ratio is $<7$. In this experiment was observed the ratio total digestible nutrients (TDN):CP of 11.4. The increase in forage uptake can be correlated with the associative positive effect that often occurs when the supplementation with grains causes increased dry matter intake and/or forage digestion. Increased dry matter intake and/or forage digestion 
results from the supplementation of limiting nutrients, present in the supplement but not in the forage, for ruminal microorganisms (e.g. nitrogen and sulfur) ${ }^{(20)}$.

The increased CP, NDF, EE, and NFC intake observed in treatments with different frequencies of supplementation can be attributed to the protein-energy supplementation effect because these increases follow the DMI increases (Table 2). Thus, the concentrated supplementation possibly provided an increased influx of protein and energy nutrients for microorganisms and host. The absolute values of total DM, CP, and NDF intake increased with the increased frequency of supplementation, however, these values did not significantly differ from each other.

Ruminants have the ability to conserve ruminal $\mathrm{N}-\mathrm{NH}_{3}$ for long periods, possibly through changes in urea permeability in the gastrointestinal tract and/or regulation of renal excretion, thereby maintaining nitrogen supply in the interval between urea supplementations(21). According to Schauer et al.(22), ruminant animals can be supplemented with protein at intervals greater than one day because the benefits of protein supplementation persist after the concentrate intake. In the present study, CP and NFC digestibility coefficients for the control treatment were significantly lower than those in the supplementation treatments. This demonstrates the positive influence of nutrients supplementation through concentrates on both CP and NFC digestibility coefficients. CP and NFC digestibility did not differ among the supplementation treatments, indicating that the studied supplementation frequencies did not influence the usage of these nutrients.

Asignificant difference in the degradation of NDF and DM was observed in relation to time, but there was no interaction between supplementation frequencies and time. Franco et al. ${ }^{(23)}$ also observed no differences in fiber degradation in supplemented animals with respect to control animals. The literature reports that increased degradable protein levels in rumen leads to microbial growth, which, in turn, accelerates the degradation of fiber and other forage components ${ }^{(24,25)}$.

The supplementation effect is often explained only by improvements in ruminal degradation conditions resulting from the increased influx of nutrients to the bacterial population. In a non-exclusionary way, the benefit may be related to an improved and more balanced supply of nutrients to ruminal microorganisms, which optimizes the animal's metabolism. The potential degradation rate of NDF and DM were achieved after 96 hours of incubation. Hess et al. ${ }^{(26)}$ also found potential degradation values at 96 hours for NDF when animals were supplemented.

The rumen $\mathrm{pH}$ is a consequence of a number of factors. It can be lowered due to the intake of easily-fermentable (soluble) carbohydrates soon after intake. The $\mathrm{pH}$ reduction occurs when the rate of production of volatile fatty acids (fermentation products) is greater than absorption through the rumen wall or passage to another compartment(22). However, despite the supply of concentrate containing easilyfermentable carbohydrates, obtained $\mathrm{pH}$ values did not reach levels that are harmful to the animal. According to Hiltner and Dehority ${ }^{(27)}$, the optimal $\mathrm{pH}$ range for fiber digestion is from 6.6-7.0; the digestion is severely reduced at $\mathrm{pH}$ less than 6.2 and even more so at $\mathrm{pH}$ less than 6.0. The effect of supplementation on ruminal $\mathrm{pH}$ was not 
observed, indicating that the supply of protein-energy supplementation has not been sufficient to reduce rumen $\mathrm{pH}$ in supplemented animals.

As expected, the protein-energy supplementation led to an increase in total rumen $\mathrm{N}-\mathrm{NH}_{3}$ concentration. The same was observed by ${ }^{(28,29)}$. Nevertheless, it is important to note that, regardless of the observed lower $\mathrm{N}-\mathrm{NH}_{3}$ concentrations in the control animals, the ruminal $\mathrm{N}-\mathrm{NH}_{3}$ concentrations were always within the range of 2 to $5 \mathrm{mg} /$ $\mathrm{dL}$, suggested by Satter and Slyter ${ }^{(30)}$ as the minimum level that does not limit fiber fermentation and degradation. Perhaps in these cases, cattle supplemented in low frequencies were able to maintain efficiency for nitrogen $(\mathrm{N})$ as a consequence of their ability to recycle N, as reviewed by Reynolds and Kristensen ${ }^{(31)}$.

The highest total ruminal $\mathrm{N}-\mathrm{NH}_{3}$ concentration was observed in animals supplemented daily (7WK treatment) when compared to those in the 3WK and 5WK treatments. Cappelloza et al. ${ }^{(29)}$ also observed greater ruminal $\mathrm{N}^{-N_{3}}$ concentration in animals supplemented on a daily basis when compared to those supplemented on alternate days. This indicates that the less frequent supplementation led to decreased ruminal $\mathrm{N}-\mathrm{NH} 3$ concentrations when compared to daily supplementation. Wickerham et al.(32) demonstrated that the less frequent supplementation leads to a greater dependence on $\mathrm{N}$ recycling to sustain the rumen $\mathrm{N}$ required levels compared to daily supplementation regimens.

\section{Conclusions}

Despite the fact that the $\mathrm{N}-\mathrm{NH}_{3}$ concentration in the $3 \mathrm{WK}$ and $5 \mathrm{WK}$ was lower than in the 7WK treatment, no negative effect was observed on the remaining productive and digestive parameters in these groups.

Reduction in protein-energy supplementation frequency of daily to 3WK or 5WK does not negatively affect intake, digestibility and degradability of nutrients in beef cattle receiving low quality hay.

\section{Acknowledgment}

The present study was funded by FUNDECT (Fundação de Apoio ao Desenvolvimento do Ensino, Ciência e Tecnologia do Estado de Mato Grosso do Sul) protocol n.139/05.

\section{Conflict of interest}

The authors declare that they have no competing interests.

\section{References}

1. Morais JAS, Queiroz MFS, Keli A, Vega A, Fiorentini G, Canesin RC, Reis RA, Berchielli TT. Effect of supplementation frequency on intake, behavior and performance in beef steers grazing Marandu grass. 
Protein-energy supplementation frequency on ruminal variables, intake and digestibility in steers receiving low quality hay D'Oliveira M.C. et al.

Anim Feed Sci Technol 2014; 189: 63-71.

2. Bonadimann R, Moraes EHBK, Moraes KAK, Pina DS, Oliveira AS, Meneses DM, Stinguel H, Almeida CM. Frequency of concentrate supplementation for grazing beef cattle. Semina: Ciênc Agrár 2017 ; 38: 21412150.

3. Silva-Marques RP, Zervoudakis JT, De Paula NF, Hatamoto-Zervoudakis LK, Silva PIJLR, Matos NBN. Effects of protein-energetic supplementation frequency on growth performance and nutritional characteristics of grazing beef cattle. Trop Anim Health Prod 2018; 50: p 495-501.

4. Atkinson RL, Toone CD, Robinson TJ, Harmon DL, Ludden PA. Effects of ruminal protein degradability and frequency of supplementation on nitrogen retention, apparent digestibility, and nutrient flux across visceral tissues in lambs fed low-quality forage. J Anim Sci 2010; 88: 727-736.

5. Farmer CG, Cochran RC, Nagaraja TG, Titgemeyer EC, Johnson DE, Wickersham TA. Ruminal and host adaptations to changes in frequency of protein supplementation. J Anim Sci 2004; 82 : 895-903.

6. NRC- National Research Council. Nutrient requirements of beef cattle. 7a Ed. Washington DC: National Academic Press ; 1996. 242p. English.

7. Cappelle ER, Valadares Filho SC, Coelho Da Silva JF, Cecon PR. Estimativas do valor energético a partir de características químicas e bromatológicas dos alimentos. Rev Bras Zootec 2001; 30: 1837-1856.

8. Valadares Filho SC, Magalhães KA, Rocha Junior VR, et al. Tabelas brasileiras de composição de alimentos para bovinos. 2.ed. Viçosa, MG: UFV; 2006. 329p.

9. Sniffen CJ, O'connor JD, Van Soest PJ, Fox DG, Russell JB. A net carbohydrate and protein system for evaluating cattle diets: Il. Carbohydrate and protein availability. J Anim Sci 1992; 70: 3562-3577.

10. Ribeiro SS, Vasconcelos JT, Morais MG, Ítavo CBCF, Franco GL. Effects of ruminal infusion of slow-release polymer-coated urea or conventional urea on apparent nutrient digestibility, in situ degradability, and rumen parameters in cattle fed low-quality hay. Anim Feed Sci Technol 2011; 164: 53-61.

11. Huntington JA, Givens DI. The in situ technique for studying the rumen degradation of feeds: a review of the procedure. Nutr Res Rev Series B 1995; 65: 63-93.

12. AOAC. Official methods of analysis, 17th ed. Gaithersburg, MD : Association of Official Analytical Chemists; 2000. English.

13. Van Soest PJ, Robertson JB, Lewis BA. Methods for dietary fiber, neutral detergent fiber, and nonstarch polyssacarides in relation to animal nutrition. J Anim Sci 1991; 74: 3583-3597.

14. NRC- National Research Council. Nutrient requirements of dairy cattle. 7a Ed. Washington DC: National Academy Press; 2001. 381p. English.

15. Hall MB. Calculation of non-structural carbohydrate content of feeds that contain non-protein nitrogen. Gainesville: University of Florida ; 2000. p.A-25 (Bulletin, 339). English.

16. Fenner $\mathrm{H}$. Method for determining total volatile bases in rumen fluid by steam distillation, J Dairy Sci 1965; 48: 249-251.

17. Mcguire DL, Bohnert DW, Schauer CS, Falck SJ, Cooke RF. Daily and alternate day supplementation of urea or soybean meal to ruminants consuming low-quality cool-season forage: I- Effects on efficiency of nitrogen use and nutrient digestion. Livest Sci 2013; 155: 205-213.

18. Drewnoski ME, Poore MH, Benson GA.Effect of frequency of supplementation of a soyhulls and corn gluten feed blend on hay intake and performance of growing steers. Anim Feed Sci Technol 2011; 164: 38-44. 
19. Moore JA, Brant MH, Kunkle WE, Hopkins DI. Effects of supplementation on voluntary forage intake, diet digestibility and animal performance. J Anim Sci 1999; 77: 122-135.

20. Dixon RM, Stockdale CR. Associative effects between forages and grains: consequences for feed utilization. Aust J Agric Res 1999; 50: 757- 774.

21. Bohnert DW, Schauer RC, Bauer ML, Delcurto T. Influence of rumen protein degradability and supplementation frequency on steers consuming low quality forage: site of digestion and microbial efficiency. J Anim Sci 2002; 80:2967-2977.

22. Schauer CS, Bohnert DW, Ganskopp DC, Richards CJ, Falck SJ. Influence of protein supplementation frequency on cows consuming low-quality forage: Performance, grazing behavior and variation in supplement intake. J Anim Sci 2005; 83: 1715-1725.

23. Franco GL, Andrade PA, Bruno Filho JR, Diogo JMS. Parâmetros ruminais e desaparecimento da FDN da forragem em bovinos suplementados em pastagem na estação das águas. Rev Bras Zootec 2002; 31: 2340-2349.

24. Ortignes I, Fontenot JP, Ferry JG. Digesta flows in sheep fed poor-quality hay supplemented with urea and carbohydrates. J Anim Sci 1988; 66: 975-985.

25. Galyean ML, Owens FN. Effects of diet composition and level of feed intake on site and extent of digestion in ruminants. In: Tsuda T, Sasaki Y, Kawashima R, editors. Physiological aspects of digestion and metabolism in ruminants. New York : Academic Press ; 1991. p.483-514.

26. Hess BW, Park KK, KrysI MB, Judkins MB, Mccracken BA, Hanks DR. Supplemental protein for beef cattle grazing dormant intermediate wheatgrass pasture: effects on nutrient quality, forage intake, digesta kinetics, grazing behavior, ruminal fermentation, and digestion. J Anim Sci 1994; 72:2213-2223.

27. Hiltner P, Dehority BA. Effects of soluble carbohydrates on digestion of cellulose by pure cultures of rumen bacteria. Appl Environ Microbiol 1983; 46: 642-648.

28. Bohnert DW, Delcurto T, Clark AA, Merrill ML, Falck SJ, Harmon DL. Protein supplementation of ruminants consuming low-quality cool- or warm-season forage: differences in intake and digestibility. J Anim Sci 2011; 89: 3707-3717.

29. Cappellozza BI, Bohnert DW, Schauer CS, Falck SJ, Vanzant ES, Harmon DL, Cooke RF. Daily and alternate day supplementation of urea or soybean meal to ruminants consuming low-quality cool-season forage: II. Effects on ruminal fermentation. Livest Sci 2013; 155: 214-222.

30. Satter MK, Slyter JJ. Ruminal fermentation pattern bacterial population and ruminal degradation of feed ingredients as influenced by ruminal ammonia concentration. J Anim Sci 1974; 38: 310-320.

31. Reynolds CK, Kristensen NB. Nitrogen recycling through the gut and the nitrogen economy of ruminants: An asynchronous symbiosis. J Anim Sci 2008; 86: E293-E305.

32. Wickersham TA, Titgemeyer EC, Cochran RC, Wickersham EE, Moore ES. Effect of frequency and amount of rumen-degradable intake protein supplementation on urea kinetics and microbial use of recycled urea in steers consuming low-quality forage. J Anim Sci 2008; 86: 3089-3099. 